\title{
Mixture of commercial herbicides based on 2,4-D and glyphosate mixture can suppress the emergence of zooplankton from sediments
}

\author{
Jorge L. Portinho ${ }^{a,}{ }^{*}$, Daryl L. Nielsen ${ }^{b}$, Luana Daré ${ }^{c}$, Raoul Henry ${ }^{c}$, Régis C. Oliveira a , \\ Ciro C.Z. Branco a \\ a São Paulo State University (UNESP), Department of Biology, Aquatic Biology Laboratory, Assis, 19806-900, São Paulo, Brazil \\ b CSIRO Land and Water Flagship, University Drive, Wodonga, Victoria, 3690, Australia \\ c São Paulo State University (UNESP), Department of Zoology, Botucatu, 18618-970, São Paulo, Brazil
}

\section{H I G H L I G H T S}

- The dormant eggs represent a major source of regenerative potential in lakes.

- We examined the effect of Bratt ${ }^{\circledR}$, Roundup ${ }^{\circledR}$ and their mixture on the emergence of the dormant eggs.

- Herbicides studied reduced the number of zooplankton emerging from the dormant eggs.

- Herbicides studied can vastly diminish zooplankton populations in lakes.

\section{A R T I C L E I N F O}

\section{Article history:}

Received 4 January 2018

Received in revised form 10 March 2018

Accepted 22 March 2018

Available online 23 March 2018

Handling Editor: Jim Lazorchak

\section{Keywords:}

Pesticides

Microcrustaceans

Rotifers

Dormant egg banks

Aquatic ecotoxicology

\begin{abstract}
A B S T R A C T
It is generally assumed that zooplankton can recolonize lakes that have been exposed to pesticides, via their dormant egg banks. Hitherto, few studies have evaluated the relative importance of dormant egg bank recruitment in the re-establishment of zooplankton communities in the presence of pesticide. This study investigated the effects of commercial products Bratt ${ }^{\circledR}$ (a.i. 2,4-D), Roundup ${ }^{\circledR}$ (a.i. glyphosate) and their mixture on the emergence (abundance and taxon richness) of dormant zooplankton egg banks from natural lake sediment. Sediment samples were collected from the surface sediment $(<10 \mathrm{~cm}$ depth) in four lakes in Southeast São Paulo, Brazil. We performed a hatching experiment, in which natural lake sediments containing dormant eggs were exposed separately to Bratt ${ }^{\mathbb{R}}$ (applied concentrations ranging from 0.30 to $\left.20 \mathrm{mg} \mathrm{L}^{-1}\right)$, Roundup ${ }^{\mathbb{B}}\left(0.28-8.5 \mathrm{mg} \mathrm{L}^{-1}\right)$, and combined mixtures of all concentrations, plus one control (non-exposure to formulated herbicides) for a period of 28 days. All tested concentrations of Bratt $^{\mathbb{B}}$, Roundup ${ }^{\mathbb{B}}$ and their mixture reduced the abundance and taxon richness of emerging zooplankton (except $2 \mathrm{mg} \mathrm{L}^{-1}$ of Bratt ${ }^{\circledR}$ ). This effect was more pronounced in rotifers. In comparison, there were no negative effects on the emergence of microcrustaceans. These findings suggest that commercial products Bratt $^{\mathbb{Q}}$, Roundup ${ }^{\circledR}$ and their mixture can suppress the emergence of rotifers, thereby influencing zooplankton recruitment potential in lakes impacted by the presence of these commercial herbicides. Our results stress the importance of the need for additional studies to assess the effects of pesticides on dormant egg banks.
\end{abstract}

(c) 2018 Elsevier Ltd. All rights reserved.

\section{Introduction}

Zooplankton, including microcrustaceans (cladocerans and copepods) and rotifers, are an abundant and diversified group of

\footnotetext{
* Corresponding author. Tel.: +55 183302 5851.|

E-mail addresses: jorgeportinho@gmail.com (J.L. Portinho), Daryl.Nielsen@csiro. au (D.L. Nielsen), luanadareld@gmail.com (L. Daré), rhenry@ibb.unesp.br (R. Henry), camposregis27@gmail.com (R.C. Oliveira), czbranco@assis.unesp.br (C.C.Z. Branco).
}

invertebrates in lake ecosystems. They occupy a central position in lake food webs, as consumers of algae and bacteria, and as potential prey items for invertebrates, waterbirds and juvenile fish (Fernando, 1994). Most zooplankton taxa reproduce clonally during favourable conditions but switch to sexual reproduction in response to adverse conditions in the water column, such as predation, competition, and low oxygen and nutrients, among others (Ricci, 2001; Gyllström and Hansson, 2004). During sexual reproduction, the active life-stage of zooplankton produces dormant 
eggs, which are deposited in sediments of lakes creating a longlived bank of dormant eggs that are able to emerge and repopulate when more favourable conditions return (Hairston et al., 1995; Hairston, 1996; Brock et al., 2003).

Dormant egg banks represent a major source of regenerative potential in lake sediments. It is generally assumed that the active life-stage of most zooplankton populations eliminated from the water column by chemical pesticides are able to re-establish by emergence from the dormant egg bank (Hanazato and Yasuno, 1990; Sakamoto and Tanaka, 2013), or by dispersal by wind, water or animals (Cáceres and Soluk, 2002; Green and Figuerola, 2005; Vanschoenwinkel et al., 2008). Despite this general assumption, few studies have evaluated the relative importance of dormant egg bank recruitment in the re-establishment of zooplankton communities in the presence of pesticides. The studies that have addressed the potential effect of chemical pesticides on the dormant eggs are very limited and inconclusive. For example, Navis et al. (2013) suggested that active ingredient (a.i.) fenoxycarb pesticides suppress emergence of dormant eggs of the microcrustacean Daphnia magna, whereas a. i. carbaryl had no effect on the emergence of this species. In contrast, Möst et al. (2015), demonstrated that emergence of $D$. longispina increased when exposed to a mixture of 10 chemical contaminants, which included biocides, pesticides, and personal care products. For rotifers, Marcial et al. (2005) found that exposure to common pesticide such as diazinon, fenitrothion, methoprene and isoprothiolane decreased the emergence of Brachionus plicatilis. While these studies revealed the susceptibility of the dormant eggs of some species to pesticides in standard ecotoxicological tests, information on the effects of pesticides on the structural attributes of zooplankton communities (i.e. abundance, taxonomic richness, and diversity of emerged community) from natural lake sediment containing dormant egg banks is unknown (Angeler and García, 2005; EFSA, 2013).

Taking into account the limited existing knowledge on this issue, this study builds directly on the recent study of Gutierrez et al. (2017), which indicated a decrease in abundance and diversity of zooplankton emerging in treatments exposed to the formulated herbicide Sulfosato Touchdown ${ }^{\mathbb{B}}$ (a.i. glyphosate). In the current study, we aimed to expand our understanding by examining the individual and combined effects of two commercial herbicides Bratt $^{\circledR}$ (a.i. 2,4-D) and Roundup ${ }^{\circledR}$ (a.i. glyphosate) on the structural attributes of the emerged zooplankton community. This was assessed by comparing the abundance and taxon richness of zooplankton emerging from dormant egg banks exposed to formulated herbicides. We performed a hatching experiment, in which natural lake sediment containing dormant egg banks was exposed separately to Bratt ${ }^{\mathbb{B}}$, Roundup ${ }^{\mathbb{B}}$, and a mixture of these formulated herbicides. We selected these herbicides because they are the most commercialized herbicides in Brazil (IBAMA, 2013). In addition, application of formulated herbicides containing 2,4-D and glyphosate in combination is a common agricultural practice to control glyphosate-resistant plants (Moreira et al., 2007; Christoffoleti and Nicolai, 2016). More recently, a commercial formulation containing 2,4-D (195 g acid equivalent $\mathrm{L}^{-1}$ ) and glyphosate ( $205 \mathrm{~g}$ acid equivalent $\mathrm{L}^{-1}$ ) was developed by Dow AgroSciences, to meet this demand (Li et al., 2013; Peterson et al., 2016). Residues of 2,4-D and glyphosate are also frequently detected in Brazilian fresh waters (Albuquerque et al., 2016). The occurrence of 2,4-D and glyphosate in fresh waters has been shown to affect reproduction and adult survival of the active life-stage of most zooplankton (see review Rico-Martínez et al., 2012) and, consequently it seems possible that these herbicides could have similar adverse effects on the zooplankton that typically emerge from dormant egg banks. We tested the hypothesis that formulated products Bratt ${ }^{\mathbb{R}}$ (a.i. 2,4-D) and Roundup ${ }^{\mathbb{R}}$ (a.i. glyphosate) and their mixtures will suppress the abundance and taxon richness of the zooplankton emerging from lake sediments.

\section{Material and methods}

\subsection{Field sites and sediment collection containing dormant zooplankton eggs}

We collected sediment containing dormant zooplankton eggs from four lakes (Camargo, Cavalos, Coqueiral and Barbosa) in Southeast São Paulo, Brazil (between latitudes $23^{\circ} 08^{\prime} \mathrm{S}$ and $23^{\circ} 35^{\prime} \mathrm{S}$ and longitudes $48^{\circ} 30^{\prime} \mathrm{W}$ and $49^{\circ} 13^{\prime} \mathrm{W}^{\prime}$ ). A detailed limnological and biota description of the four lakes can be found in Granado and Henry (2008) and Panarelli et al. (2008). From each lake, sediment samples were collected on 31st January 2017 from seven equidistant sampling stations along a transect from lake shore (shallow area), stopping at pelagic zone (deep area) to sample the spatial heterogeneity of dormant eggs within the lakes (Portinho et al., 2016). At each sampling station, surface sediment samples $\left(<10 \mathrm{~cm}\right.$ depth) were collected by Van Veen grab $\left(0.06 \mathrm{~m}^{2}\right)$ and placed in a plastic bag following the methods of Nielsen et al. (2003, 2007). At each sampling station, $0.04 \mathrm{~m}^{3}$ of sediment was collected from $0.4 \mathrm{~m}^{2}$ of surface area ( 7 samples per site of dimensions $0.25 \times 0.25 \times 0.1 \mathrm{~m}$ depth) (Brock et al., 2005). The sediment was taken back to the Aquatic Biology Laboratory at São Paulo State University. As the study was not designed to compare or evaluate the dormant egg banks in each lake per se, sediment samples collected in all four lakes were combined into a single sample (pooled sample) to maximize the number of taxa available for emergence (Brock et al., 2005). Sediment samples were then lightly crushed, sieved through a $500 \mu \mathrm{m}$ mesh to remove vegetation, mixed and air dried for 8 weeks, to ensure that only dormant stages remain prior to sub-sampling and re-inundation in the hatching experiment (Nielsen et al., 2003; Brock et al., 2005).

\subsection{Experimental design for assessing the effect of formulated herbicides on emergence of zooplankton from lake sediment}

To evaluate the effects of formulated herbicides on zooplankton emergence from the sediment we conduct a hatching experiment in the laboratory. Fifty grams (dry weight) of pooled sediment sample were placed into individual trays of $0.5 \mathrm{~L}(9.5 \mathrm{~cm}$ diameter $)$ and covered with $0.3 \mathrm{~L}$ of medium solution of the respective formulated herbicide treatment (see below). Thirteen treatments (four Bratt ${ }^{\circledR}$ (a.i. 2,4-D) + four Roundup ${ }^{\circledR}$ (a.i. glyphosate) + four combined mixture + one control (without formulated herbicides)) were performed with four replicates each.

Individual trays exposed to appropriate treatment type and control were incubated at a constant temperature $\left(25^{\circ} \mathrm{C}\right)$ in a 12:12 h light/dark cycle to simulate optimum hatching conditions in the study area (i.e. southeast, São Paulo, Brazil) (Iglesias et al., 2016). The emergence (i.e. abundance and taxon richness of the emerged zooplankton community) over the time following the exposure to contaminants was monitored for 28 days. For emergence, each tray was sampled twice weekly by gently pouring the water from each tray through a $50 \mu \mathrm{m}$ sieve with minimum disturbance to the sediment, and the retained material was preserved in $70 \%$ alcohol. Samples were then identified and counted under dark-field microscopy (Zeiss, Stemi 2000). Samples were identified to the lowest taxonomic unit possible (Koste, 1978; Reid, 1985; Elmoor-Loureiro, 1997). The sediment remaining in each container was re-inundated with solution of the appropriate treatment type. The solutions were applied by a single pulsed dose without the renewal or replacement of water in trays during the 
course of 28 days of the experiment. This represents a scenario for a direct over spray of a lake. Twenty-eight days has been shown to be sufficient for overall emergence success as a prerequisite in zooplankton abundance and diversity studies (Vandekerkhove et al., 2005), and twice-weekly sampling minimizes the potential for reproduction by any individuals that emerge (Nielsen et al., 2003, 2007).

\subsection{Formulated herbicides treatments}

The formulated herbicides used in the hatching experiment were commercial formulation Bratt $^{\circledR}$ (a.i. 2,4-D) with $67 \%$ of acid equivalent and $42.1 \%$ of coadjuvants, commercial formulation Roundup $^{\circledR}$ (a.i. glyphosate) with $36 \%$ of acid equivalent and $68.4 \%$ of coadjuvants, and a combined mixture of both herbicides. The selection of a commercial formulation instead of the active principle isolated is based on way used in current agricultural practices. The treatment concentrations of Bratt $^{\circledR}$, Roundup ${ }^{\circledR}$ separate or in combination used in the hatching experiment are shown in Table 1.

The nominal concentrations were calculated from the percentage of the acid equivalent $(\mathrm{w} / \mathrm{v})$ reported in the label of the commercial product. The medium solution was prepared by dilution of a specific amount of each compound in distilled water and then added the solution to the appropriate treatments. The analytical determination of the actual concentration of the formulated herbicide in each treatment was performed once from subsamples of the treatment solution taken after one day of begin of the hatching experiment. The Bratt ${ }^{\circledR}$ treatments were analyzed using gas chromatography/mass spectrometry (GC/MS) according to the standard US-EPA 8270 method (US-EPA, 1996), and Roundup ${ }^{\circledR}$ treatments were analyzed in accordance with USEPA 300.1 method using ion chromatography (Metrohm 930 compact IC Flex) (US-EPA, 1997).

\subsection{Data analysis}

Zooplankton count data were averaged across four replicates to give abundances and taxon richness of emerged zooplankton in

Table 1

Bratt $^{\circledR}$ (a.i. 2,4-D), Roundup ${ }^{\circledR}$ (a.i. glyphosate) and mixture nominal concentrations used in the hatching experiment. The analytical determination of the actual concentration of the formulated herbicides in each treatment were performed once from subsamples of the treatment solution taken after one day of begin of the hatching experiment.

\begin{tabular}{|c|c|c|}
\hline Treatments & Nominal concentration $\left(\mathrm{mg} \mathrm{L}^{-1}\right)$ & Actual concentration $\left(\mathrm{mg} \mathrm{L}^{-1}\right)$ \\
\hline \multicolumn{3}{|c|}{$\operatorname{Bratt}^{\circledR}$ (a.i. 2,4-D) } \\
\hline $\mathrm{T} 1$ & $0.30^{\mathrm{a}}$ & 0.21 \\
\hline $\mathrm{T} 2$ & $2^{\mathrm{b}}$ & 0.30 \\
\hline T3 & $10^{\mathrm{d}}$ & 3.95 \\
\hline $\mathrm{T} 4$ & $20^{d}$ & 7.84 \\
\hline \multicolumn{3}{|c|}{ Roundup $^{\circledR}$ (a.i. glyphosate) } \\
\hline $\mathrm{T} 1$ & $0.28^{\mathrm{a}}$ & 0.11 \\
\hline $\mathrm{T} 2$ & $3.5^{\mathrm{b}}$ & 1.18 \\
\hline T3 & $6.0^{c}$ & 2.03 \\
\hline $\mathrm{T} 4$ & $8.5^{\mathrm{d}}$ & 2.30 \\
\hline \multicolumn{3}{|l|}{ Mixture } \\
\hline $\mathrm{T} 1$ & $0.30+0.28$ of mixture & $0.19+0.29$ of mixture \\
\hline $\mathrm{T} 2$ & $2+3.5$ of mixture & $1+0.89$ of mixture \\
\hline T3 & $10+6$ of mixture & $4.45+1.60$ of mixture \\
\hline $\mathrm{T} 4$ & $20+8.5$ of mixture & $6.30+2.68$ of mixture \\
\hline
\end{tabular}

${ }^{\mathrm{a}}$ Maximum concentration for irrigation and animal consumption allowed under Brazilian law (National environmental council, 2005).

b Based on the manufacture's recommended application rate to control plagues (Giesy et al., 2000).

c The highest concentration found in a natural aquatic environment (Edwards et al., 1980).

d Range of concentrations established in standard acute ecotoxicological tests on the sensitivity of species of zooplankton (Rico-Martínez et al., 2012). each treatment within each formulated herbicides prior to analysis.

We applied a one-way ANOVA to test for effects of Bratt ${ }^{\mathbb{R}}$, Roundup $^{\circledR}$ and in combined mixture treatments separately on the abundance and taxon richness of emerged total zooplankton community. The term total zooplankton refers to the combined abundances and richness of microcrustaceans and rotifers. Separate analyses were performed on data for each taxa group of microcrustaceans (cladocerans and copepods) and rotifers. In the case of significant differences, Tukey's post hoc test was used to assess which treatments were statistically different. In all cases, the assumptions of normality and homoscedasticity were checked and the data were transformed (square root) as necessary. Statistical analyses were undertaken using SSPS version 20.0 (SPSS Inc., Chicago, IL, U.S.A.). Significant differences were inferred at an $\alpha$-level of 0.05 .

\section{Results}

\subsection{Dormant zooplankton egg community}

A total of 34 taxa, comprised of 20 microcrustaceans (including unidentified juvenile stages of Copepoda) and 14 rotifers, were identified during hatching experiment in all treatments (see Supplementary data 1 ; Table S1).

\subsection{Effects of formulated herbicides on the structural attributes of dormant zooplankton egg banks}

The herbicide Bratt $^{\circledR}$ reduced the emergence of total zooplankton and rotifer communities from the lake sediments, but not microcrustaceans (Fig. $1 \mathrm{a}-\mathrm{d}$ ). Total zooplankton abundance was similar in the control, T1, T3 and T4, but was significantly lower in T2 compared to the control (Fig. $1 \mathrm{a}, \mathrm{b}$ ). Total zooplankton richness presented a similar pattern of emergence over time, and did not differ significantly between treatments in the final of experiment (Table 2; Fig. 1 c, d). Rotifer abundance and richness were significantly lower in all four tested Bratt ${ }^{\circledR}$ treatments compared to the control, and there was no differences between the four tested Bratt $^{\circledR}$ treatments (Fig. 1 a, c; see Tukey's post hoc test in Supplementary data 2; Table S2). The time trajectories based on cumulative emergence data indicate that there was a steady increase in abundance and richness in the control over time as compared all four tested Bratt ${ }^{\circledR}$ treatments (Fig. 1 b, d). For microcrustaceans, however, there were no significant differences detected for

Table 2

$F$ ratio and significance level of ANOVA investigating the effects of formulated herbicides treatments on abundance and taxon richness of total zooplankton, rotifers and microcrustaceans response variables. Bold $P$ values indicates statistically significant effects $(n=4, P<0.05)$.

\begin{tabular}{|c|c|c|c|c|c|c|}
\hline \multirow{2}{*}{$\begin{array}{l}\text { Response variables } \\
\text { Total zooplankton }\end{array}$} & \multicolumn{2}{|c|}{$\begin{array}{l}\text { Bratt }^{\mathbb{B}} \text { (a.i. 2,4- } \\
\text { D) }\end{array}$} & \multicolumn{2}{|c|}{$\begin{array}{l}\operatorname{Roundup}^{(\mathbb{B}} \text { (a.i. } \\
\text { glyphosate) }\end{array}$} & \multicolumn{2}{|c|}{ Mixture } \\
\hline & $F$ & $P$ & $F$ & $P$ & $F$ & $P$ \\
\hline Total abundance & 3.01 & 0.05 & 6.23 & $<0.01$ & 9.55 & $<0.01$ \\
\hline $\begin{array}{l}\text { Taxon richness } \\
\text { Rotifers }\end{array}$ & 1.57 & 0.23 & 5.55 & $<0.01$ & 7.87 & $<0.01$ \\
\hline Total abundance & 5.57 & $<0.01$ & 6.88 & $<0.01$ & 6.38 & $<0.01$ \\
\hline $\begin{array}{l}\text { Taxon richness } \\
\text { Microcrustaceans }\end{array}$ & 5.55 & $<0.01$ & 9.76 & $<0.01$ & 7.88 & $<0.01$ \\
\hline Total abundance & 0.96 & 0.45 & 0.90 & 0.49 & 0.75 & 0.57 \\
\hline $\begin{array}{l}\text { Taxon richness } \\
\text { Taxon abundance }\end{array}$ & 1.03 & 0.42 & 1.17 & 0.36 & 1.27 & 0.32 \\
\hline Cladocerans & 1.02 & 0.42 & 9.15 & 0.06 & 7.30 & 0.12 \\
\hline Macrothrix spinosa & 0.50 & 0.73 & 2.68 & 0.61 & 2.89 & 0.57 \\
\hline Copepod & 0.55 & 0.70 & 1.73 & 0.19 & 10.13 & 0.03 \\
\hline Copepod nauplii & 0.93 & 0.92 & 1.91 & 0.16 & 7.52 & 0.11 \\
\hline
\end{tabular}


(a) Total abundance

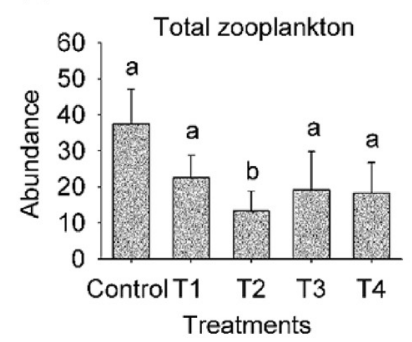

(b) Cumulative abundance

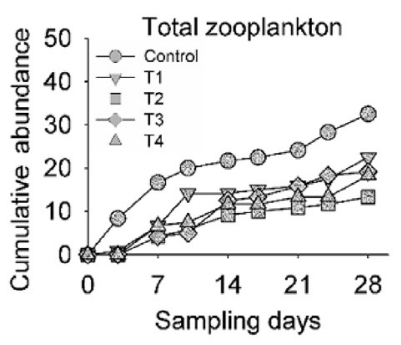

(c) Total taxon richness

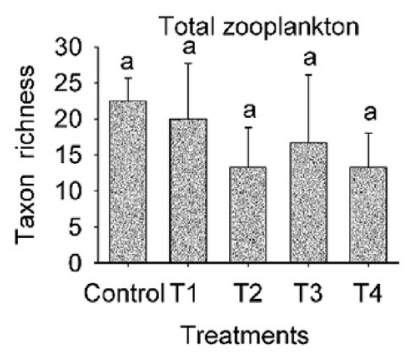

(d) Cumulative taxon richness

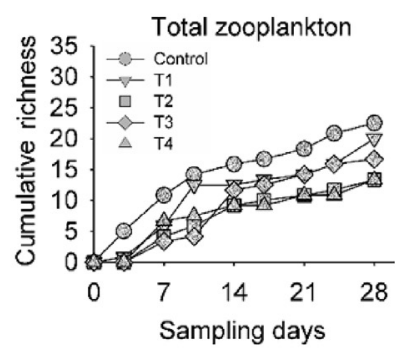

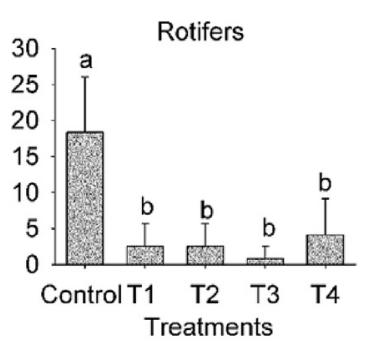
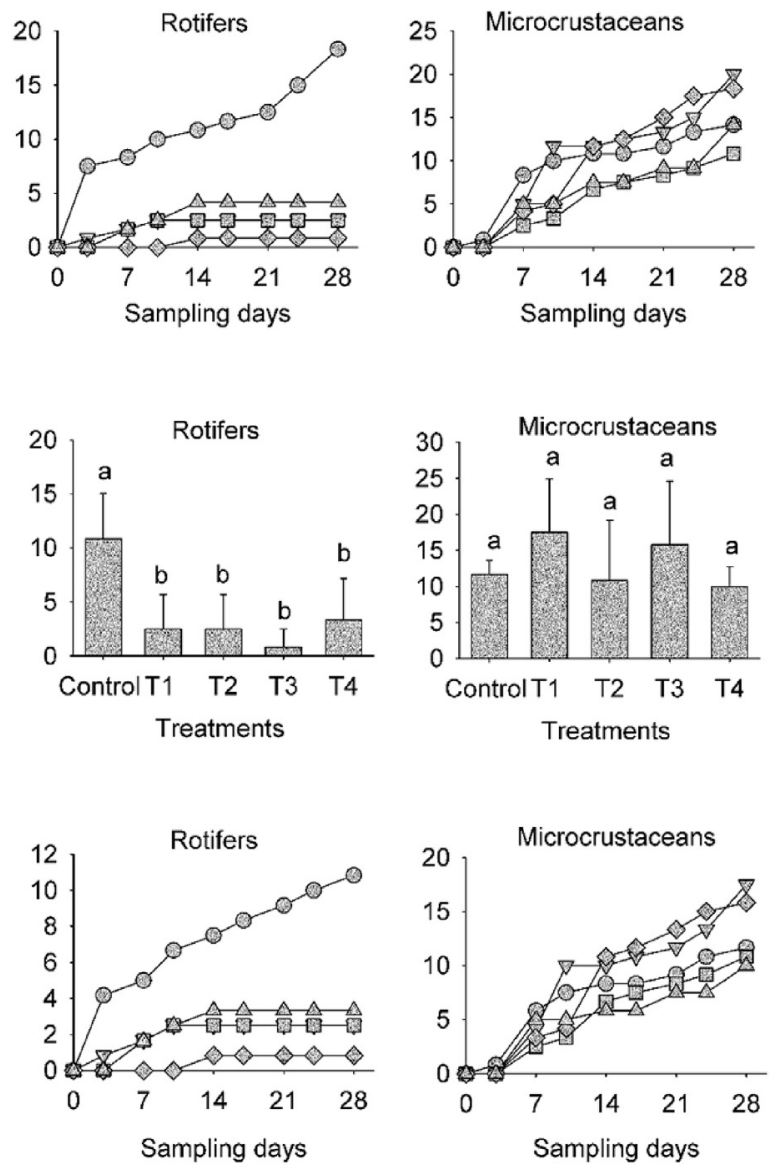

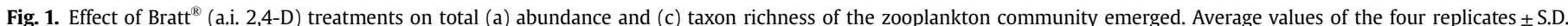

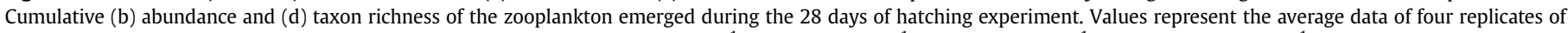

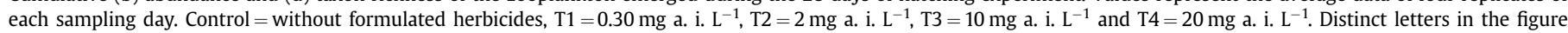
indicate significant differences $(P<0.05$, One Way ANOVA, followed by Tukey's post hoc test).

abundance and taxon richness between all treatments (Table 2; Fig. $1 \mathrm{a}-\mathrm{d}$ ). Further examination showed that cladocerans, copepods, and the taxa Macrothrix spinosa and copepod nauplii consistently emerged under all four tested Bratt ${ }^{\circledR}$ treatments and did not differ significantly as compared to the control (Table 2; Fig. 2 a-d).

The herbicide Roundup ${ }^{\circledR}$ also reduced the emergence of total zooplankton and rotifers from the lake sediments, whereas it had no significant negative effects on microcrustaceans (Table 2; Fig. 3 a-d). In both total zooplankton and rotifers, abundance and taxon richness after exposure to all four Roundup ${ }^{\mathbb{B}}$ treatments were significantly lower than control, and there were no differences between the four tested treatments (Fig. 3 a, c; see Tukey's post hoc test in Supplementary data 2; Table S3). All four Roundup ${ }^{\circledR}$ treatments caused a reduction in cumulative emergence of total zooplankton and rotifers over time (Fig. 3 b, d). Conversely, no significant differences were found for microcrustacean abundance and taxon richness between all treatments throughout and at conclusion of the hatching experiment (Table 2; Fig. $3 \mathrm{a}-\mathrm{d}$ ). Further investigation revealed that cladocerans, copepods, and the taxa Macrothrix spinosa and copepod nauplii consistently emerged under all four tested Roundup ${ }^{\circledR}$ treatments (except copepod and copepod nauplii at T1), and did not differ significantly as compared to the control (Table 2; Fig. 2 a-d).

Similar to individual formulated herbicides, mixtures reduced the emergence of total zooplankton and rotifers from the lake sediments, whereas it appeared to have no significant effect on microcrustaceans (Table 2; Fig. 4 a-d). Total zooplankton and rotifer abundance and richness were significantly lower in all four tested combined mixture treatments compared to the control, with 

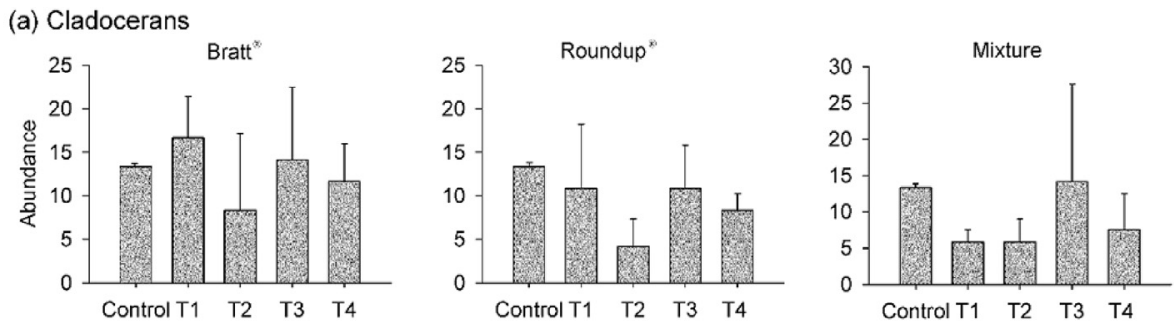

(b) Macrothrix spinosa
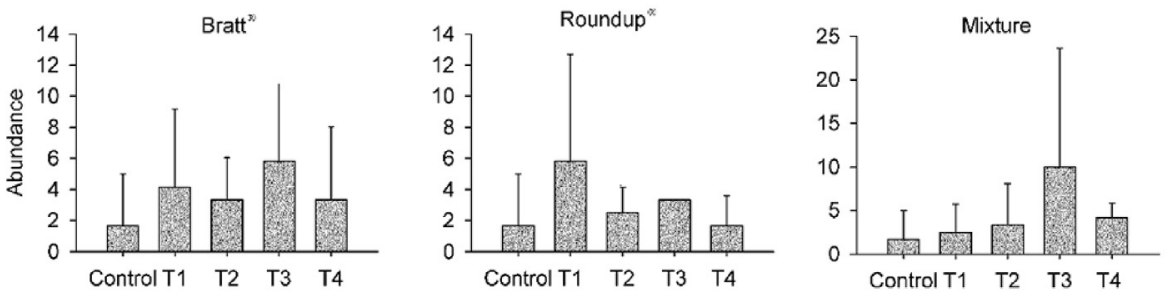

(c) Copepod
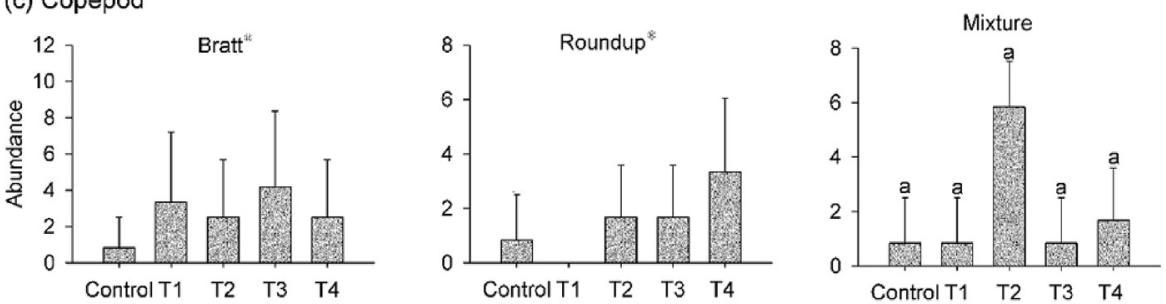

(d) Copepod nauplii
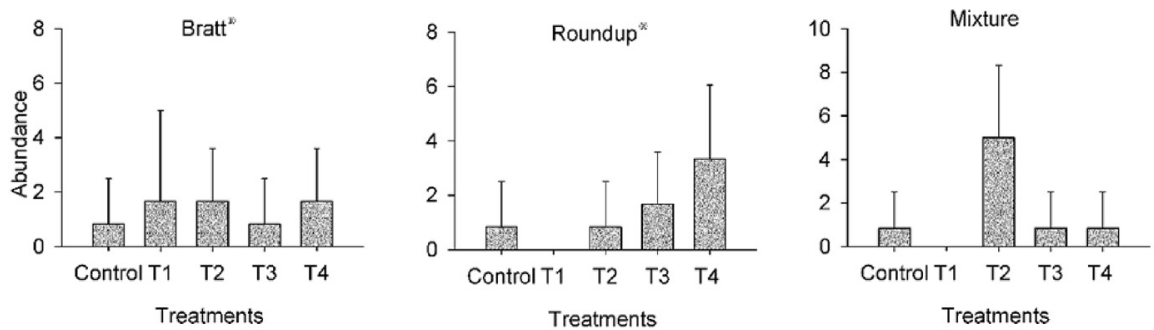

Fig. 2. Effect of Bratt ${ }^{\mathbb{B}}$ (a.i. 2,4-D), Roundup ${ }^{\circledR}$ (a.i. glyphosate) and mixture treatments on abundance of (a) cladocerans, (b) Macrothrix spinosa, (c) copepods, and (d) copepod nauplli (for code of formulated herbicides treatments see Figs 1, 3 and 4). Average values of the four replicates \pm S.D. Same letters in $2 \mathrm{c}$ indicate Copepod abundances varied significantly across mixture treatment $(P<0.05$, One Way ANOVA), but the treatment effect was not identified when a Tukeys post hoc test was applied.

no significance differences between the four mixture treatments (Fig. 4 a, c; see Tukey's post hoc test in Supplementary data 2; Table S4). All four-mixture treatments caused a reduction in cumulative emergence of total zooplankton and rotifers during the course of the experiment (Fig. 4 b, d). For microcrustaceans, abundance and richness in all four tested treatments did not show significant differences from the control or between the four mixture treatments (Table 2; Fig. 4 a-d). Further examination shown that cladocerans and the taxa Macrothrix spinosa and copepod nauplii do no differ in terms of abundance across the range of mixture treatments and control. Copepod abundances varied significantly across mixture treatment, but the treatment effect was not identified when a Tukey's post hoc test was applied (Table 2; Fig. 2 c).

\section{Discussion}

With the exception of a study by Gutierrez et al. (2017) that demonstrated that the formulated herbicide Sulfosato Touchdown ${ }^{\circledR}$ (a.i. glyphosate) disrupts the process of emergence of zooplankton from dormant egg banks, little information is available on the effects of chemical pesticides on dormant zooplankton egg banks. This study extended these findings of Gutierrez et al. (2017) and tested the hypothesis that commercial herbicides $\operatorname{Bratt}^{\mathbb{B}}$ (a.i. 2,4-D) and Roundup ${ }^{\circledR}$ (a.i. glyphosate) separate or in combination can impact upon dormant zooplankton egg banks communities in lakes. Results from the study supported this hypothesis and suggest that the formulated herbicides studied have the potential to suppress emergences of zooplankton from lake sediments. In addition, our findings show that the effects of Bratt ${ }^{\circledR}$ and Roundup ${ }^{\circledR}$ on emergences, separate or in combination, differed markedly between the dormant egg banks of microcrustaceans and rotifers.

\subsection{Effects of formulated herbicides on emergence of dormant zooplankton egg banks}

The emerged total zooplankton communities from all four Roundup $^{\circledR}$ (a.i. glyphosate) and mixture treatments tested were significantly less abundant and rich than those communities emerging non-exposed to formulated herbicides. For Bratt ${ }^{\circledR}$ (a.i. 
(a) Total abundance
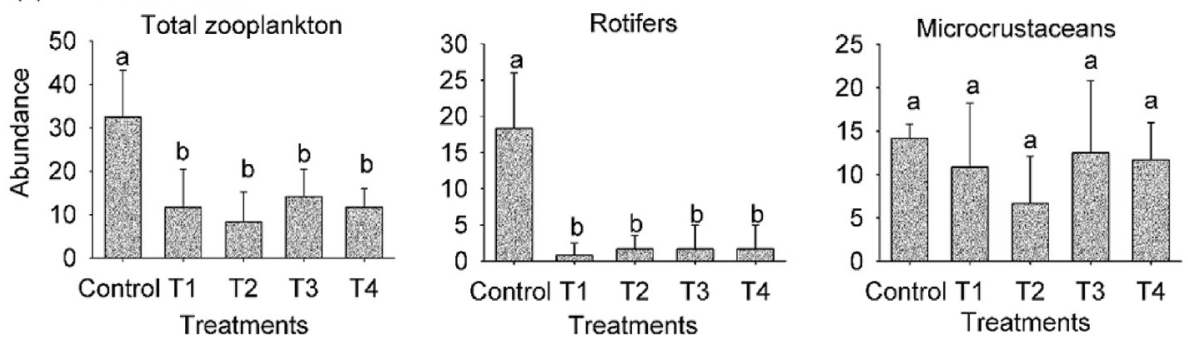

(b) Cumulative abundance
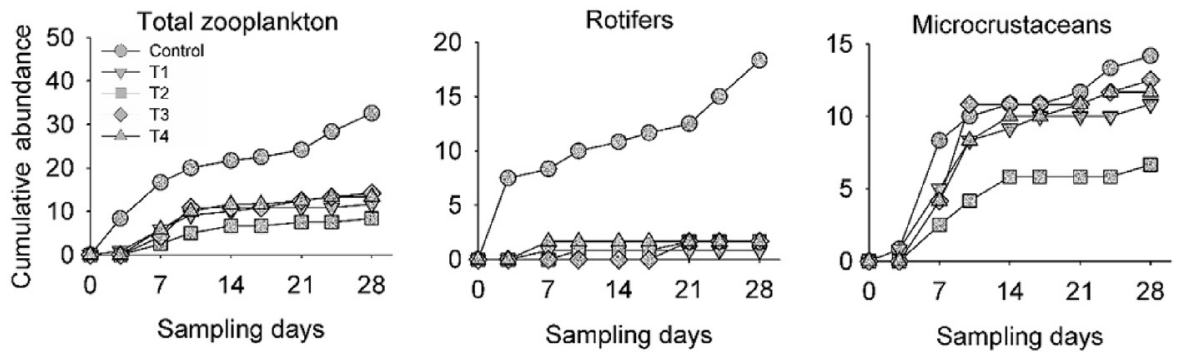

(c) Total taxon richness
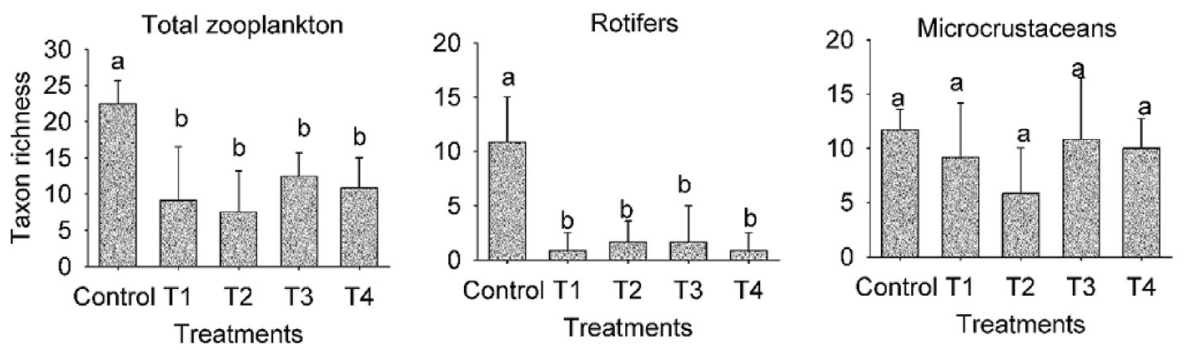

(d) Cumulative taxon richness
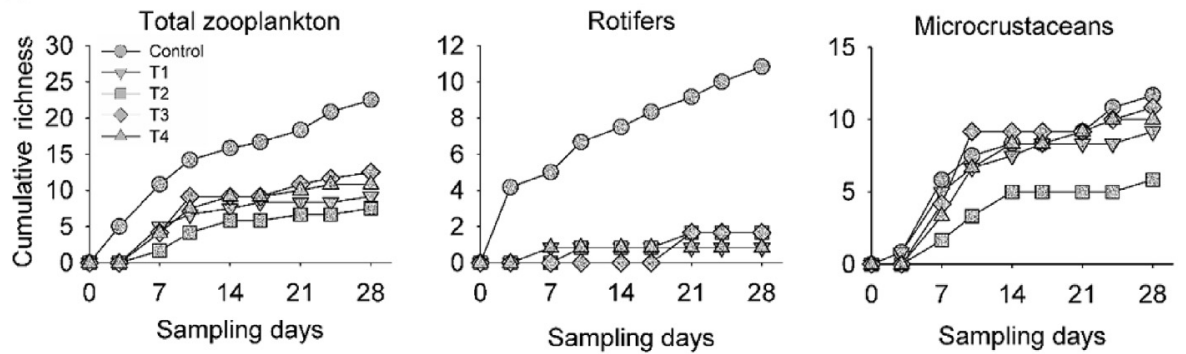

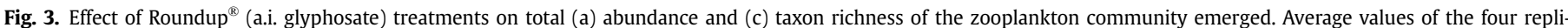

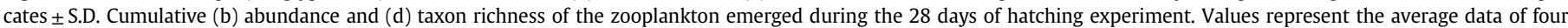

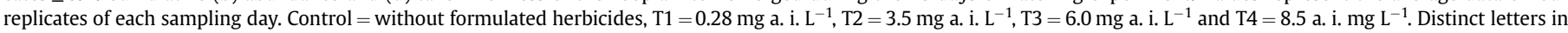
the figure indicate significant differences $(P<0.05$, One Way ANOVA, followed by Tukey's post hoc test).

2,4-D), total zooplankton showed a significant decrease in abundance of taxa emerging only in treatment T2 $\left(2 \mathrm{mg}\right.$ a. i. $\mathrm{L}^{-1}$, see Table 2; Fig. 1a), while taxon richness of total zooplankton did not differ significantly from the control. The decreased emergence of zooplankton organisms in the presence of formulated herbicides may occur via direct impact of chemical herbicides on dormant eggs, by killing the diapausing embryo inside the dormant egg of sensitive organisms, and via effects of herbicides on the dormancybreak system, result in loss of egg viability or in mortality soon after emergence (Angeler and García, 2005).

When we examined the effects of formulated herbicides on the emergences of individual taxa groups of microcrustaceans and rotifers, the following emergence patterns was observed: All treatments of Bratt ${ }^{\mathbb{B}}$ and Roundup ${ }^{\mathbb{R}}$ and combinations appear to have reduced the emergence of rotifers from lake sediment, but, in contrast, did not affect the emergence of microcrustaceans. This emergence pattern is sustained by the results, which showed that the abundance and richness of the emerged microcrustacean community did not differ significantly from those not exposed to formulated herbicides, while the abundance and richness of the emerged rotifer community in the formulated herbicides treatments were significantly lower than those communities emerging from non-exposure to herbicides. This difference in the emergence of rotifers and microcrustaceans suggests that many microcrustaceans taxa are capable of tolerating the formulated products tested, including the studied concentrations, whereas dormant rotifer eggs are highly sensitive to the toxicity of these formulated herbicides. 
(a) Total Abundance
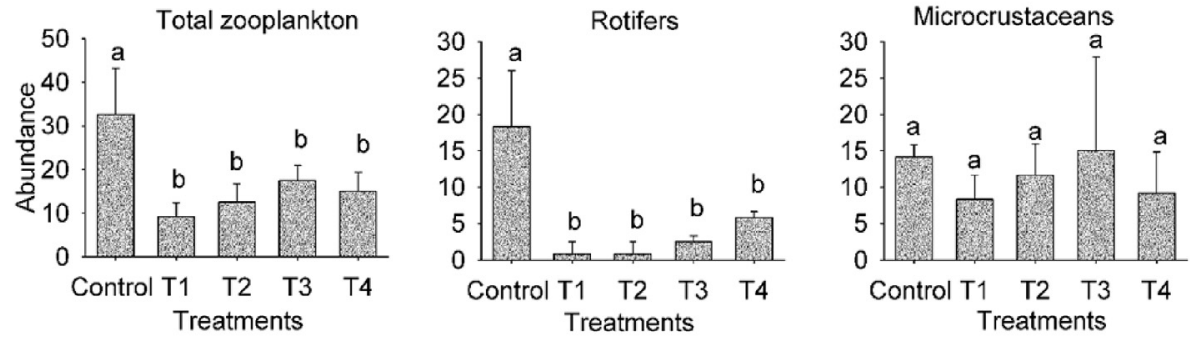

(b) Cumulative abundance
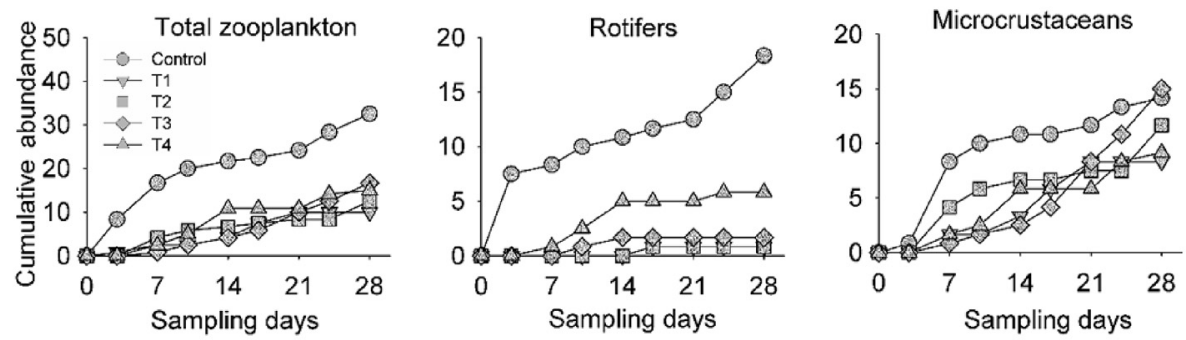

(c) Total taxon richness
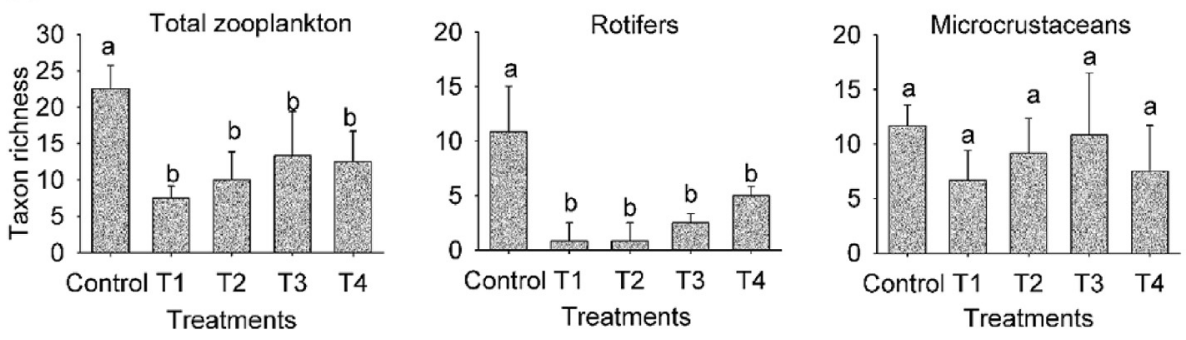

(c) Cumulative taxon richness
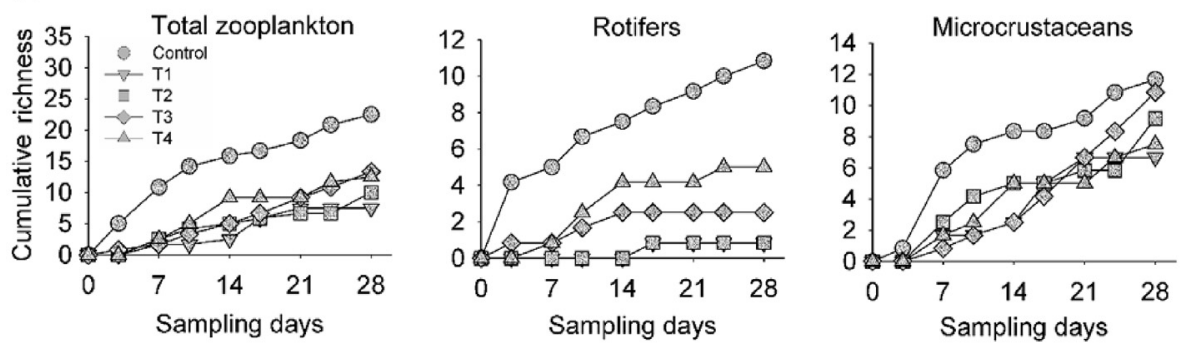

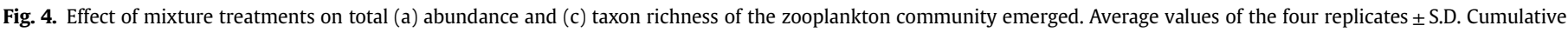

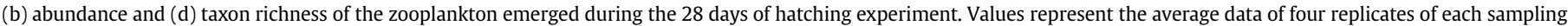

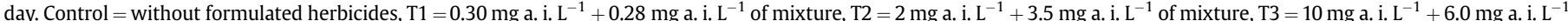

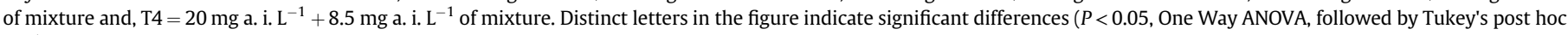
test).

Although we cannot determine what factor was responsible for the difference in response between microcrustaceans and rotifers to the herbicides studied (see below), we can suggest that the structural differences between the dormant eggs of these two groups are involved in these responses. Thus, the types and characteristics of the dormant eggs, including egg sizes and morphological complexity, could possibly explain the observed differences in sensitivity to the toxicity of the pesticides (Raikow et al., 2006). Microcrustacean (Cladocera) dormant eggs are large (range 200-400 $\mu \mathrm{m}$ ), have thick, multi-layered membranes and are covered with an additional external envelope derived from carapace, called the ephippium (Brendonck and De Meester, 2003). In comparison, dormant rotifer eggs are smaller (range $80-200 \mu \mathrm{m}$ ) and are surrounded by a thick membrane made of three layers
(Ricci, 2001). Whereas the ephippium of cladocerans can offer protection, although limited (see Navis et al., 2015), for diapausing embryos against penetration of pesticides during embryonic development, the small size of dormant rotifer eggs may result in faster diffusion of pesticides into the embryos, and may damage or kill the diapausing embryo inside the thick membrane, rendering it unviable. For instance, Raikow et al. (2006) demonstrated that the embryos of microcrustacean species Daphnia mendotae encased in protective ephippium were less sensitive to the toxicity of biocide SeaKleen ${ }^{\circledR}$ than were the dormant eggs of rotifer species Brachionus plicalitis, and attributed this difference to a greater fragility in the membrane surrounding the diapausing embryo in the latter species.

Our results highlight the complex nature of formulated 
herbicides Bratt ${ }^{\mathbb{R}}$ and Roundup ${ }^{\mathbb{R}}$ in potentially suppressing the emergence of some taxa likely to be influenced by products tested, or by favouring the emergence of taxa unaffected by the products tested (Navis et al., 2013; Möst et al., 2015). However, this study focused on assessing the overall effects of each formulated herbicides, and of combined mixtures, within the context of an ecological community in the first instance, and did not attempt to disentangle the mechanisms underlying how these formulated herbicides affect species-specific emergence. There is, therefore, an important future tailored experiment to examine the effects of herbicides on dormant eggs, to confirm which (if any) taxa's dormant eggs are rendered unviable. Formulated herbicides containing 2,4-D and glyphosate as active ingredients, separate or in combination, might be promising candidates for initial studies because of their widespread usage and potential for contamination of aquatic systems (Relyea, 2005).

\subsection{Ecological implications and concluding remarks}

Results from our hatching experiment demonstrate that Bratt ${ }^{\mathbb{R}}$ (a.i. 2,4-D) and Roundup ${ }^{\circledR}$ (a.i. glyphosate) and their mixtures suppress the emergence of zooplankton organisms owing to impacts on the dormant fraction of the community, in particular the rotifer communities, and thereby influence zooplankton recruitment potential in lakes impacted by the presence of formulated herbicides studied. The demonstrated impact, if occurring in nature, might produce higher emergence of tolerant taxa, with subsequent changes to species dominance and community composition (Stampfli et al., 2014). In addition, as egg banks can potentially be depleted by frequent and intense exposure to pesticides, higher vulnerability to stress as well as a decrease in population size stability may lead to increased risk of local extinction (Snell and Serra, 2000). This would be expected to occur within isolated lakes surrounded by agricultural land. Finally, another potential effect of pesticide exposure would occur in the lake food webs (Hanazato, 2001). Zooplankton typically emerge in high abundance in lakes, and they are usually the most important food source for low secondary consumers such as insect larvae and juvenile fish (Fernando, 1994).

Our results suggest that the current prioritization of traditional drivers (e.g. nitrogen and phosphorus levels, and habitat degradation) that affect aquatic environments may be misleading if formulated herbicides are not also considered (Beketov et al., 2013). Finally, recent attempts to develop guidelines for protecting aquatic organisms have focused on emergence from dormant egg banks within the context of an ecological community (see EFSA (2013) for more details). In this context, our results provide insights into emergence patterns in the presence of formulated herbicides Bratt ${ }^{\circledR}$ and Roundup ${ }^{\mathbb{B}}$ and their mixtures, with potential implications for studies related to environmental risk to, and integrity assessment of, aquatic ecosystems.

\section{Conclusion}

In conclusion, the present study reveals the potential for formulated herbicides Bratt $^{\circledR}$ (a.i. 2,4-D) and Roundup ${ }^{\circledR}$ (a.i. glyphosate) and their mixtures found in lakes to affect ecology of zooplankton communities via their impact on dormant egg banks. In addition, our results showed that the emergence pattern of zooplankton in the presence of formulated herbicides can differ at the broad taxonomic level (e.g. microcrustaceans $v s$ rotifers). Our finds, therefore, point to a relevant ecotoxicological issue that emphasizes the importance of, and need for, further studies assessing the effects of pesticides on dormant egg banks and aquatic ecosystems.

\section{Declarations of interest}

None.

\section{Acknowledgments}

We are grateful to CAPES (Coordination for the improvement of higher Education Personnel) for the scholarship to JLP. We also thank Henrique Oliveira for help with the hatching experiment. We thank the anonymous reviewers for their careful reading of our manuscript and their many insightful comments and suggestions.

\section{Appendix A. Supplementary data}

Supplementary data related to this article can be found at https://doi.org/10.1016/j.chemosphere.2018.03.156.

\section{References}

Albuquerque, A.F., Ribeiro, J.S., Kummrow, F., Nogueira, A.J.A., Montagner, C.C. Umbuzeiro, G.A., 2016. Pesticides in Brazilian freshwaters: a critical review. Environ. Sci. Process. Impacts 18, 779-787. https://doi.org/10.1039/ c6em00268d.

Angeler, D.G., García, G., 2005. Using emergence from soil propagule banks as indicators of ecological integrity in wetlands: advantages and limitations. J. North Am. Benthol. Soc. 24, 740-752. https://doi.org/10.1899/05-025.1.

Beketov, M.A., Kefford, B.L., Schäfer, R.B., Liess, M., 2013. Pesticides reduce regional biodiversity of stream invertebrates. Proc. Natl. Acad. Sci. U. S. A. 27, 11039-11043. https://doi.org/10.1073/pnas.1305618110.

Brendonck, L., De Meester, L., 2003. Egg banks in freshwater zooplankton: evolutionary and ecological archives in the sediment. Hydrobiologia 491, 65-84. https://doi.org/10.1023/A:1024454905119.

Brock, M.A., Nielsen, D.L., Crosslé, K., 2005. Changes in biotic communities developing from freshwater wetland sediments under experimental salinity and water regimes. Freshw. Biol. 50, 1376-1390. https://doi.org/10.1111/j.13652427.2005.01408.x.

Brock, M.A., Nielsen, D.L., Shiel, R.J., Green, J.D., Langley, J.D., 2003. Drought and aquatic community resilience: the role of eggs and seeds in sediments of temporary wetlands. Freshw. Biol. 48, 1207-1218. https://doi.org/10.1046/ j.1365-2427.2003.01083.x.

Cáceres, C.C., Soluk, D.A., 2002. Blowing in the wind: a field test of overland dispersal and colonization by aquatic invertebrates. Oecologia 131, 402-408. https://doi.org/10.1007/s00442-002-0897-5.

Christoffoleti, P.J., Nicolai, M., 2016. Resistência de plantas daninhas a herbicidas: definições, bases e situação no Brasil e no Mundo, 4 ed. Marcelo N. (Orgs.) Piracicaba: HRAC-BR, Christoffoleti, PJ, p. 262p.

Edwards, W.M., Triplett Jr., G.B., Kramer, R.M., 1980. A watershed study of glyphosate transport in runoff. J. Environ. Qual. 9, 661-665.

EFSA, 2013. Guidance on Tiered Risk Assessment for Plant Protection Products for Aquatic Organisms in Edge-of-field Surface Waters.

Elmoor-Loureiro, L.M.A., 1997. Manual de Identificação de Cladóceros Límnicos do Brasil. Universa, Taguatinga.

Fernando, C.H., 1994. Zooplankton, fish and fisheries in tropical freshwaters. Hydrobiologia 272, 105-123. https://doi.org/10.1007/BF00006516.

Giesy, J.P., Dobson, S., Solomon, K.R., 2000. Ecotoxicological risk assessment for Roundup herbicide. Rev. Environ. Contam. Toxicol. 167, 35-120. https://doi.org/ 10.1007/978-1-4612-1156-3_2.

Granado, D.C., Henry, R., 2008. The influence of the hydrologic pulse on the water physical and chemical variables of lateral lakes with different connection levels to Paranapanema Rivers in the mouth zone at Jurumirim Reservoir (São Paulo Brasil). Acta Limnol. Bras. 20, 265-275.

Green, A.J., Figuerola, J., 2005. Recent advances in the study of long-distance dispersal of aquatic invertebrates via Birds. Divers. Distrib. 11, 149-156. https://doi.org/10.1111/j.1366-9516.2005.00147.x.

Gutierrez, M.F., Battauz, Y., Caisso, B., 2017. Disruption of the hatching dynamics of zooplankton egg banks due to glyphosate application. Chemosphere 171, 644-653. https://doi.org/10.1016/j.chemosphere.2016.12.110.

Gyllström, M., Hansson, L., 2004. Dormancy in freshwater zooplankton: induction, termination and the importance of benthic-pelagic coupling. Aquat. Sci. 66, 274-295. https://doi.org/10.1007/s00027-004-0712-y.

Hairston, N.G., 1996. Zooplankton egg banks as biotic reservoirs in changing environments. Limnol. Oceanogr. 41, 1087-1092. https://doi.org/10.4319/ lo.1996.41.5.1087.

Hairston, N.G.J., Van Brunt, R.A., Kearns, C.M., 1995. Age and survivorship of diapausing eggs in a sediment egg bank. Ecology 76, 1706-1711. https://doi.org/ $10.2307 / 1940704$.

Hanazato, T., 2001. Pesticide effects on freshwater zooplankton: an ecological perspective. Environ. Pollut. 112, 1-10. https://doi.org/10.1016/S0269-7491(00) 00110-X. 
Hanazato, T., Yasuno, M., 1990. Influence of time of application of an insecticide on recovery patterns of a zooplankton community in experimental ponds. Arch. Environ. Con. Toxicol. 19, 77-83. https://doi.org/10.1007/BF01059815.

IBAMA, 2013. Relatório de Comercialização de Agrotóxico- Boletim anual de produção, importação, exportação e vendas de agrotóxico no Brasil. Ministério do Meio Ambiente, Brasília. http://www.ibama.gov.br/areas-tematicas-qa/ relatorios-decomercializacao-de-agrotoxicos/pagina-3. (Accessed 13 May 2016).

Iglesias, C., Bonecker, C., Brandão, L., Crispim, M.C. Eskinazi-Sant'Anna, E.M. Gerhard, M., Portinho, J.L., Maia-Barbosa, P., Panarelli, E., Santangelo, J.M., 2016. Current knowledge of South American cladocerans diapause: a brief review. Int. Rev. Hydrobiol. 101, 91-104.

Koste, W., 1978. Rotatoria die Rädertiere Mitteleuropas begründet von Max Voight. Monogononta. Gebrüder Borntraeger, Berlin.

Li, M., Tank, H., Kennedy, A., Zhang, H., Downer, B., Ouse, D., Liu, L., 2013. Enlist Duo herbicide: a novel 2, 4-D plus glyphosate premix formulation with low potential for off-target movement. In: Pesticide Formulation and Delivery Systems: 32nd Volume, Innovating Legacy Products for New Uses. ASTM International, West Conshohocken, PA.

Marcial, H.S., Hagiwara, A., Snell, T.W., 2005. Effect of some pesticides on reproduction of rotifer Brachionus plicatilis Müller. Hydrobiologia 546, 569-575. https://doi.org/10.1007/1-4020-4408-9_57.

Moreira, M.S., Nicolai, M., Carvalho, S.J.P., Christoffoleti, PJ., 2007. Resistência de Conyza canadensis e C. bonariensis ao herbicida glyphosate. Planta Daninha 25, $157-164$.

Möst, M., Chiaia-Hernandez, A.C., Frey, M.P., Hollender, J., Spaak, P., 2015. A mixture of environmental organic contaminants in lake sediments affects hatching from Daphnia resting eggs. Environ. Toxicol. Chem. 2, 338-345. https://doi.org/ $10.1002 /$ etc. 2808 .

National environmental council, 2005. Resolução no. 357 de 17 de março de 2005. Diário Oficial da União 53, 58-66.

Navis, S., Waterkeyn, A., Putman, A., De Meester, L., Vanermen, G., Brendonck, L. 2015. Timing matters: sensitivity of Daphnia magna dormant eggs to fenoxycarb exposure depends on embryonic developmental stage. Aquat. Toxicol. 159, 176-183. https://doi.org/10.1016/j.aquatox.2014.12.016.

Navis, S., Waterkeyn, A., Voet, T., De Meester, L., Brendonck, L., 2013. Pesticide exposure impacts not only hatching of dormant eggs, but also hatchling survival and performance in the water flea Daphnia magna. Ecotoxicology 5 , 803-814. https://doi.org/10.1007/s10646-013-1080-y.

Nielsen, D.L., Brock, M.A., Crosslé, K., Harris, K., Healey, M., Jarosinski, I., 2003. The effects of salinity on aquatic plant germination and zooplankton hatching from two wetland sediments. Freshw. Biol. 48, 2214-2223. https://doi.org/10.1046/ j.1365-2427.2003.01146.x.

Nielsen, D.L., Brock, M.A., Petrie, R., Crosslé, K., 2007. The impact of salinity pulses on the emergence of plant and zooplankton from wetland seed and egg banks. Freshw. Biol. 52, 784-795. https://doi.org/10.1111/j.1365-2427.2006.01714.x.

Panarelli, E.A., Casanova, S.M.C., Henry, R., 2008. The role of resting eggs in the recovery of zooplankton community in a marginal lake of the Paranapanema River (São Paulo, Brazil), after a long drought period. Acta Limnol. Bras. 20, $73-88$.
Peterson, M.A., McMaster, S.A., Riechers, D.E., Skelton, J., Stahlman, P.W., 2016. 2,4-D past, present, and future: a review. Weed Technol. 30, 303-345. https://doi.org/ 10.1614/WT-D-15-00131.1.

Portinho, J.L., Nielsen, D.L., Ning, N., Paul, W., Nogueira, M.G., 2016. Spatial variability of aquatic plant and microfaunal seed and egg bank communities within a forested floodplain system of a temperate Australian river. Aquat. Sci. 79, 515-527. https://doi.org/10.1007/s00027-016-0514-z.

Raikow, D.F., Reid, D.F., Maynard, E.E., Landrum, P.F., 2006. Sensitivity of aquatic invertebrate resting eggs to SeaKleen (Menadione): a test of potential ballast tank treatment options. Environ. Toxicol. Chem. 25, 552-559. https://doi.org/ 10.1897/05-142R1.1.

Reid, J.W., 1985. Chave de identificação para as espécies continentais sul americanas de vida livre da ordem Cyclopoida (Crustacea, Copepoda). Bol. Zool., Univ. São Paulo 9, 17-143.

Relyea, R.A., 2005. The impact of insecticides and herbicides on the biodiversity and productivity of aquatic communities. Ecol. Appl. 15, 618-627. https://doi.org/ $10.1890 / 03-5342$.

Ricci, C., 2001. Dormancy patterns in rotifers. Hydrobiologia 446, 1-11. https:// doi.org/10.1023/A:1017548418201.

Rico-Martínez, R., Arias-Almeida, J.C., Pérez-Legaspi, I.A., Alvarado-Flores, J.E., RetesPruneda, J.L., 2012. In: Hasannen, M.N. (Ed.), Adverse Effects of Herbicides on Freshwater Zooplankton, Herbicides - Properties, Synthesis and Control of Weeds. ISBN: 978-953-307-803-8, InTech, Available from: http://www. intechopen.com/books/herbicides-properties-synthesis-and-control-ofweeds/ adverse-effects-of-herbicides-on-freshwater-zooplankton.

Sakamoto, M., Tanaka, Y., 2013. Different tolerance of zooplankton communities to insecticide application depending on the species composition. J. Ecol. Environ. 36, 141-150. https://doi.org/10.5141/ecoenv.2013.018.

Snell, T.W., Serra, M., 2000. Using probability of extinction to evaluate the ecological significance of toxicant effects. Environ. Toxicol. Chem. 19, 2357-2363. https:// doi.org/10.1002/etc.5620190928.

Stampfli, N.C., Knillmann, S., Noskov, Y.A., Schafer, R.B., Liess, M., Beketov, M.A., 2014. Environmental stressors can enhance the development of community tolerance to a toxicant. Ecotoxicology 23, 1690-1700. https://doi.org/10.1007/ s10646-014-1308-5.

U.S. Environmental Protection Agency, 1996. Method 8270C: Semi Volatile Organic Compounds by Gas Chromatography/Mass Spectrometry (GC/MS). U.S. Environmental Protection Agency, Washington, DC.

U.S. Environmental Protection Agency, 1997. Method 300.1: Determination of Inorganic Anions in Drinking Water by Ion Chromatography, Revision 1.0. U.S Environmental Protection Agency, Washington, DC.

Vandekerkhove, J., Declerck, S., Brendonck, L., Conde-Porcuna, J.M., Jeppesen, E., Meester, L.D., 2005. Hatching of cladoceran resting eggs: temperature and photoperiod. Freshw. Biol. 50, 96-104. https://doi.org/10.1111/j.13652427.2004.01312.x.

Vanschoenwinkel, B., Gielen, S., Vandewaerde, H., Seaman, M., Brendonck, L., 2008. Relative importance of different dispersal vectors for small aquatic invertebrates in a rock pool metacommunity. Ecography 31, 567-577. https:// doi.org/10.1111/j.0906-7590.2008.05442.x. 